\title{
Editorial: Teaching and learning English in the age of COVID-19: Reflecting on the state of TESOL in a changed world
}

\section{Rod Neilsen \\ Michiko Weinmann \\ Ruth Arber \\ Co-Editors}

As this issue of TESOL in context goes to press, we are looking back on a period of close to 18 months since the COVID-19 pandemic became a reality for Australia. The immediate, farreaching and ongoing impact of the pandemic on education has been captured and documented in much academic and professional debate to date (Kenley, 2020; Zentrum für Lehrerinnen- und Lehrerbildung Bamberg (ZLB), 2020). Restrictions on travel resulting from the pandemic have severely impacted teachers, students and teacher educators all over the world (Tran, 2020).

These are challenging times for education, and for our profession. Employment in the TESOL field, for a long time precarious because of casualisation, has been affected by a high number of job redundancies as a result of the significant decline in international student numbers, especially in vocational and higher education sectors. The entry of international EAL/D students into primary and secondary schools has also sharply fallen as Australia's borders have been closed to all but returning Australian residents and citizens.

The Australian ELICOS sector had previously contributed more than $\$ 2$ billion to an international education industry worth upwards of $\$ 37.6$ billion (Jones \& Forbes, 2020). Australia had the highest ratio of international students per capita in the world by a significant margin, representing $26.7 \%$ of the total student body in 2018. Research has begun into the impacts of the pandemic on TESOL in Australia. In June 2020, the Australian Council of TESOL Associations (ACTA) began surveying teachers and managers for capturing the impacts on all stakeholders in the sector, and results are expected to be published soon on the 
ACTA website https://tesol.org.au/. Further, in a project enabled by QATESOL, Dr Sue Creagh at the University of Queensland has been investigating the experiences of EAL/D teachers and school personnel across Queensland schools and AMEP programs during lockdown. She is documenting in particular those activities and practices which were most optimal and most challenging for delivery of EAL/D support and programs, and examining "what has changed' in the delivery of EAL/D programs as a consequence of the lockdown. Continuing engagement with the challenges faced by the sector will be key in navigating what is expected to be a long-term recovery process.

While borders will remain closed for some time, schools, universities and educational providers overall are gradually returning to onsite activity in Australia. Nevertheless, a blended mode of learning and teaching, bringing together digital and in situ practices, has been adopted across many educational domains. This has opened up space for renewed conversations around for example, educational delivery, remote learning and educational disadvantage (Dabrowski, Nietschke, Taylor-Guy, \& Chase, 2020; UNICEF, 2020). We are still experiencing national border closures and lockdowns implemented at short notice in response to new COVID-19 outbreaks and clusters, such as the Victorian seven day 'circuit-breaker' in effect at the time of writing. A survey by Monash University educators (Heffeman et al. 2021) has captured perceptions of these ongoing impacts; some positive findings were that the shift to remote schooling was largely successful in Australia. While policy and public debate as well as media reporting in Australia have often been characterised by critical perceptions of teachers' work (Shine, 2020), remote learning has shifted some of those societal views and attitudes as expressed in the following reflection by a parent: "Day one I sat with him in his room all day, and by the end of the day I was exhausted and about to pen a letter to Canberra to increase teachers' salaries immediately" (Duffy \& Kent, 2020).

This move towards a more nuanced understanding of the complex work that teachers do has been an atypical and long overdue shift for the profession. The study by Heffeman et al (2021) also found that there is perceived merit in a hybrid or more flexible approach to schooling, but that equitable access to technology and academic support is crucial. While online or blended learning delivery has been increasingly implemented in Australian education pre-pandemic, the social, embodied and face-to-face dimensions of learning - Zoom fatigue aside - remain 
important for many learners (TEQSA, 2020). As Johnson (2021) put it, recovering intimacy may be the biggest challenge facing postpandemic educational institutions.

Besides this, the lack of academic and language support for international students in higher education was already of concern, and this has worsened as located student access to Australian institutions has weakened (Blackmore 2020; Nguyen \& Balakrishnan, 2020). The class, sociocultural and socioeconomic differences in the ways that parents can support their children's schooling and academic aspirations have been well documented (Arber, 2008; Rizvi 2009). Drane et al's (2020) report on the impact of COVID-19, and the subsequent implementation of home-schooling, on the achievement of vulnerable students highlights the crucial role of adequate study support and pastoral care, including language support (Poulton \& Yoo, 2020). Parents, students and teachers are struggling to adapt teaching and learning to the complexities of COVID times. These complexities are compounded as the nuances of linguistic, cultural, and classed diversities impact on the ways that education takes place within fenced, globally integrated, local spaces.

The different kinds of educational challenges that we have been experiencing have been further contributed to by the shifting geopolitics in our region. Pre-pandemic, the majority of international students in Australia came from China. The pandemic has exacerbated already existing tensions between China and Australia, with far-reaching implications for diplomacy and trade and business relations, as well as education (Power, 2021). The uncertainty around when travel restrictions will be lifted, and the recent implementation of travel bans from India into Australia, are expected to have long-term effects on inter-country relations in the region and the movement of international students (Jha, 2021).

We are unlikely to return to any kind of pre-pandemic 'normal', as "what will happen post-pandemic (whenever that may be) will depend on the path we traverse now" (Jha, 2021).

The geopolitical situation is one of a number of factors that may impact the discourses of English as the global language in the years to come. International TESOL education has experienced continuous growth by capitalising on the worldwide spread and dominance of English as a key skill for 21st century education, as promoted by global education policy agendas (Arber, Weinmann \& Blackmore, 2021). The current tensions raise questions about whether these may continue to shift perceptions and language 
ideologies of English as the assumed de facto 'global lingua franca' from the perspective of a "seemingly taken-for-granted Western superiority mentality" (Ha, 2013, p. 163).

The paper in this issue by Skourdoumbis and Madkur contributes to the broader debates in the field that seek to critically analyse and reframe the hegemonic status of English as a global educational commodity of political-economic power (O'Regan, 2020). Drawn from a larger research project that investigated how beliefs about teaching (Buehl \& Beck, 2014) of English language educators shaped their pedagogy and practice, Skourdoumbis and Madkur's study explores teachers' perceptions of the (lack of) symbolic and linguistic capital (Bourdieu, 1979) of English language in the context of pesantren (Islamic boarding schools) in Indonesia. The stories of their research participants illustrate how teachers reflect on and complexly navigate the pedagogical challenges emerging from the discursive tensions (Razfar \& Rumenapp, 2012) between English "as the pre-eminent language of an advanced global capitalism" and the issues linked to an advanced globalisation as teachers work within the unique confines of "...the socio-cultural micro-contexts of pesantren schools" (Skourdoumbis \& Madkur, this issue).

As illustrated in the example of the pesantren education system, a deeper engagement with the 'entanglements' of English in "everyday, simultaneous activities and material encounters... may concern not only political economy but also assemblages of linguistic resources, identifications, artefacts and places" (Pennycook, 2020, p. 232). This appears to carry particular significance in recent times which have been impacted by a global refocusing on national identity, geopolitical tensions and the geopolitics of language (Weinmann, Slavich \& Neilsen, 2021).

In addition to international shifts in education, national education policy initiatives may provide another impetus to pause and reflect further about what our objectives are as teachers and researchers. In 2021, the Australian education sector faces another review of initial teacher education programs, which tends to measure and evaluate 'quality' teaching in terms of generalisable skill sets and performance indicators (Gore, 2021). Responses to this ministerial decision indicate a sense of imbalance between political point-scoring. Education becomes an easy target, as the ongoing grass-roots effects of the 2020 school closures "didn't just affect classrooms but all parts of the education system - teacher education programs, teacher recruitment and supply of teachers to schools in 2021" (Seddon, Arnold \& Barbousas, 2021). 
Moreover, much education research activity that could have generated new insights into how education stakeholders manage the challenges that emerged, has been put on hold or has had to be rethought due to the pandemic. This pause, arguably the largest disruption of education systems in recent times, has also highlighted the centrality of questions around the complex ethical and positional relationships between educator-researchers and educator-participants in education research.

These issues are taken up in two papers in this issue addressing the theme of practitioner-researcher collaboration. In the first, Slaughter, Choi, Nunan, Black, Grimaud and Trinh investigate the affordances and limitations of collaborative, classroom-based research. They highlight the delicate relationship between researchers and teachers. Both these groups have different priorities, which can create tensions between the need for targeted professional learning for language teachers, the generalist nature of tertiary TESOL courses, and the diverse research agendas of teacher educators. The brief of teachers is to address the language learning needs of students (Moosa, 2018). Researchers in TESOL have usually been teachers in their earlier career, but as academics their priorities have shifted. Today's academics, Moosa argues, spend much time seeking research funding, and have to meet expectations of producing research outcomes which further both pedagogical and theoretical knowledge.

Slaughter et al.'s paper offers selected results from a collaborative research project between university-based teacher educators and TESOL teachers working in an adult education centre. The tensions which arise at the nexus between theory and practice are often 'messy', as the authors describe it. In this research teacher participants are also co-researchers. Using identity texts as a pedagogical tool, the authors frame their study through the lens of recent theoretical directions in SLA. In particular they investigate the importance of translanguaging theory as a dynamic process for strategically and creatively selecting linguistic features from one unitary, complex linguistic repertoire to make meaning (García \& Li Wei, 2014; Otheguy, García, \& Reid, 2015). It is an important addition to the field as these pedagogies capitalise on the language backgrounds of their students, and aim to improve their academic achievements, as well as address social inequalities (Kirsch, 2020).

Each of the three teachers in the study gained different insights, according to their individual concerns, through a directed 
action research approach. The researchers' examination of the ways teachers gave instructions or positioned their students highlighted how teachers' expectations can impact student achievement. The examination of translanguaging as practice enabled researchers to investigate how students engage in discursive practices that strategically include their home language practices in meaning-making activities in the classroom. Personal insights into her translanguaging practices in the classroom allowed one Vietnamese teacher to explore her personal stance towards her own languages and teacher identity (García, 2014).

The second article on this theme, by Tour, Creely and Waterhouse, considers the benefits of research participation (and the competing priorities of stakeholders) from a slightly different vantage point. The focus of their study included the documentation and reporting of the successes and challenges of digital literacies education within English language programs at an Australian Community English institution. The authors focus on three episodes from the data from their longitudinal ethnographic study of adult EAL educators. The selected episodes put the spotlight on teachers' views of research, and how they view the impacts of research on education practice. For these teachers, it was a welcome opportunity to critically reflect on their teaching, enabling them to review previously taken-for-granted aspects of their work.

The research process itself gave the teachers professional learning (PL) opportunities, even if no direct PL was provided. The authors claim that the teachers' practices of participation led to the identification of a number of useful strategies, and framed the synthesising of these as a PL-like paradigm of "giving something back" to their participants. The strategies identified were those of: seeking constructive feedback (from researchers) which promoted teacher agency; engaging with researchers' work (through publications and opportunities for questioning), and embracing collegial dialogue and reflexivity (as the presence of the teacher educators generated professional dialogue and reflexivity about theory-practice connections).

Both articles on this theme of collaboration suggest how thoughtful engagement with the challenges and benefits of teacher-researcher collaboration dynamics is key for generating research that connects theory and practice. It fractures what has become an artificial dichotomy that "most teachers have been trained to accept" (Kumaravadivelu, 2003, p. 19), and re-presents it in ways meaningful to all stakeholders in education. Parallel to 
this is another dichotomy, the separation of the roles of teaching and research, which Stewart (2006) and others have critiqued as less than helpful for TESOL. Institutions themselves, i.e. schools and universities, reinforce these binary notions by setting expectations. Editors and authors are encouraged to draw a clear line between teaching and research. The 'messiness' of such collaborations, as Slaughter and her colleagues put it, suggests a non-binary way forward.

As the articles in this issue illustrate, the experience of dichotomies - which can be varied and ubiquitous as they extend to professional, institutional, relational, cultural and spatial encounters - is a common occurrence among educators. The interrogation of how educators navigate these experiences has been an important focus of scholarly work that seeks to interrogate 'common-sense' understandings framing them (Arber 2012). The aim to unsettle and shift those understandings in order to inform and empower transformative educational practice has been a longenvisaged direction of the academic and classroom-based work enacted by practitioners in TESOL, EAL/D and Languages disciplines (Weinmann et al. 2020).

As we write this editorial, Melbourne has gone into its fourth lockdown, and South Australia has closed its border with Victoria. The intensified experience of geographical boundaries during the pandemic through international and national border closures, restrictions of movement within a $5 \mathrm{~km}$ radius from home, and the reinforcement of a social distance of 1.5 meters in public spaces, has also heightened people's awareness about the importance of language and communication in times when 'connection' becomes disrupted. There have been encouraging flow-on effects for the language teaching profession emergent from the pandemic, for example, the global spike of interest in language learning during lockdowns (Hardach, 2021), and - while not without controversy - policy initiatives such as the Australian Federal Government's funding changes for universities, which aim to increase the numbers of graduates in areas of expected employment growth, including the study of languages (Weinmann \& Welsh, 2021).

However, a key theme identified in longitudinal data generated from one of the editorial team's recent projects (Investigating the teaching contexts and curriculum policy stances of EAL/D and Languages teachers in Australia, 2015-2020) brought to the fore a challenge for many language educators. They find themselves navigating the continuing dichotomy between the fallacy of economic factionalism in the policy advocacy for TESOL 
and Languages education, and what they perceive as the lived experiences of languaging (Swain, 2006) and language study for their students and communities. As 'Claire', a generalist primary and language teacher in a rural government school states:

I have never ever heard a country student ask me: 'Why are we studying a language, does it make me money?' Never once have they seen learning this skill as a financial incentive ...I show the world around them ...how a language helps this...and they would be able to see the world around them, and how it relates to having a language.

The notion of the 'value' of language(s) in seeing and navigating an increasingly complex world that 'Claire' sees articulated in the interactions she engages in with her students is reiterated by 'Sue':

The arts and languages have to advocate for value, which is fascinating because in the middle of all these horrific fires and droughts that my community has been in, the thing that has brought courage and hope to my community ... is the arts and culture that have helped bring us together. And I think that ... we kind of forget that the arts bring an important aspect of humanity into our lives, shall we say.

A special education and languages teacher in a community that had been affected by natural disasters for some years, 'Sue' reflects on the key role that language, culture and communication have in bringing people together, especially in times of crisis. The interview with 'Sue', which was conducted in early 2020 when the full extent of the impact of the COVID-19 pandemic in Australia was yet to be seen, provides a poignant reminder of what lies at the heart of a forward-looking vision and agenda for education, as governments and education systems are busy planning to return to the status quo of (economic) operations in pre-pandemic times. The voices of educators, students and communities indicate that being 'successful' in education and work, and being 'successful' in another language, are rather by-products of the empowerment that teachers and researchers try to foster in language learners. While the disruptions that the education sector has been experiencing are still continuing, the crisis could yet provide a unique moment to 'shift the conversation' towards a crucial reframing of what we do as teachers and researchers in a postpandemic world; as mentioned earlier, recent studies have shown an increase in public trust in teachers. As language educators, we may therefore be in a unique position to reclaim and extend our 
position as key social actors in the engagement of learners and their communities.

\section{References}

Andreotti, V., \& de Souza, L. (2012). (Towards) global citizenship education 'otherwise.' In V. Andreotti \& L. de Souza (Eds.), Postcolonial perspectives on global citizenship education (pp. 1-8). New York/London: Routledge.

Arber, R., Weinmann, M., \& Blackmore, J. (2021). Rethinking Languages education: Dismantling instrumentalist agendas. In: R. Arber, M. Weinmann \& J. Blackmore (Eds.). Rethinking Languages Education: Directions, Challenges and Innovations (pp. 1-12). Abingdon: Routledge, Taylor \& Francis.

Arber, R. (2012), Encountering an-other : the culture of curriculum and inclusive pedagogies. In Z. Bekerman and T. Geisen (Eds.), International handbook of migration, minorities and education: understanding cultural and social differences in processes of learning (pp. 461-477). Dordrecht: Springer.

Arber, R. (2008). Race, ethnicity and education in globalised times. Dordrecht: Springer.

Bourdieu, P. (1979). Symbolic Power. Critique of Anthropology, 4(1314), 77-85.

Buehl, M. M., \& Beck, S. J. (2014). The relationship between teachers' beliefs and teachers' practices. In H. Fives \& M. G. Gill (Eds.) The International Handbook of Research on Teachers' Beliefs (pp. 66-84). Abingdon: Routledge.

Blackmore, J. (2020). The carelessness of entrepreneurial universities in a world risk society: A feminist reflection on the impact of Covid-19 in Australia. Higher Education Research and Development, 39(7), 1332-1336.

Dabrowski, A., Nietschke, Y., Taylor-Guy, P., \& Chase, A-M. (2020). Mitigating the impacts of COVID-19: Lessons from Australia in remote education. Australian Council for Educational Research. https://doi.org/10.37517/978-174286-618-5

Dobinson, T., \& Buchorim, S (2016) 'Catering for EAL/D students' language needs in mainstream classes: Early childhood teachers' perspectives and practices in one Australian setting'. Australian Journal of Teacher Education, 41(2). doi:10.14221/ajte.2016v41n2.3 
Drane, C., Vernon, L., \& O’Shea, S. (2020). 'Vulnerable learners in the age of COVID 19: A scoping review. The Australian Educational Researcher. Retrieved from https://link.springer. com/article/10.1007/s13384-020-00409-5

Duffy, C., \& Kent, L. (2020). Parents reflect on homeschooling as teachers voice fears about schools during coronavirus pandemic https://www.abc.net.au/news/2020-04-26/coronavirushomeschooling-remote-learning-public-privateschools/12177112 (26 April 2020)

García, O. (2014). Countering the dual: Transglossia, dynamic bilingualism and translanguaging in education. In R. Rubdy \& L. Alsagoff (Eds.), The global-local interface, language choice and hybridity (pp. 100-118). Bristol, UK: Multilingual Matters.

García, O., \& Wei, L. (2014). Translanguaging: Language, bilingualism and education. New York: Palgrave Macmillan.

Gore, J. (2021). Yes, quality teaching improves student outcomes. But that means all teachers need support - not just those in training, https://theconversation.com/yes-quality-teaching-improvesstudent-outcomes-but-that-means-all-teachers-need-supportnot-just-those-in-training-160101 (4 May 2021)

Ha, P. L. (2013). Issues surrounding English, the internationalisation of higher education and national cultural identity in Asia: a focus on Japan, Critical Studies in Education, 54(2), 160-175. https://doi.org/10.1080/17508487.2013.781047

Hardach, S. (2021). Language learning spiked during lockdowns, commercial providers say. But when no-one can travel, and the job market looks unstable, why have people turned toward language now?, https://www.bbc.com/worklife/article/20201230why-are-we-learning-languages-in-a-closed-world (7 January 2021).

Heffernan, A., Magyar, B., Bright, D., \& Longmuir, F. (2021). The Impact of COVID-19 on Perceptions of Australian Schooling: Research Brief. Monash University.

Jha, R. (2021). Reinvigorating the Australia-India relationship during the Pandemic, https://www.internationalaffairs.org. $\mathrm{au} /$ australianoutlook/reinvigorating-the-australia-indiarelationship-during-the-pandemic/ (7 May 2021).

Johnson, M. (2021). Communicative Intimacy and Social Media, https://postpandemicuniversity.net/2021/05/22/ communicative-intimacy-and-social-media/ 
Jones, A., \& Forbes, O. (2020) Arena newsletter 5 May 2020. https://arena.org.au/weve-been-sick-for-a-while-englishlanguage-education-industrys-problems-run-deeper-thancovid-19/

Kenley, D. (Ed.) (2020). Teaching about Asia in a time of pandemic. Ann Arbor: The Association for Asian Studies.

Kirsch, C. (2020) Opening minds to translanguaging pedagogies. System, 92, 1-11.

Kumaravadivelu, B. (2003). Beyond methods: Macrostrategies for language teaching. New Haven, CT: Yale University Press.

Nguyen, T, K., \& Balakrishnan, V. D. (2020). International students in Australia - during and after COVID-19. Higher Education Research and Development, 39(7), 1372-1376.

Otheguy, R., García, O., \& Reid, W. (2015). Clarifying translanguaging and deconstructing named languages: A perspective from linguistics. Applied Linguistics Review, 6(3), 281-307.

O'Regan, J. (2020). Global English and political economy: an immanent critique. Abingdon: Taylor \& Francis.

Pennycook, A. (2020). Translingual entanglements of English. World Englishes, 39(2), 222-235. https://doi.org/10.1111/ weng. 12456

Poulton, P., \& Yoo, R. (2020). Re-negotiating teacher identities: reflections on student wellbeing and online learning during COVID-19. British Education Research Association. Retrieved from https://www.bera.ac.uk/blog/renegotiatingteacher-identities-reflections-on-student-wellbeing-andonline-learning-during-covid-19

Power, J. (2021). Confucius Institutes at Australian universities could be the next casualty of strained Beijing-Canberra ties. Retrieved from https://www.scmp.com/week-asia/politics/ article/3135021/confucius-institutes-australian-universitiescould-be-next (28 May 2021)

Razfar, A., \& Rumenapp, J. C. (2012) Language ideologies in English learner classrooms: critical reflections and the role of explicit awareness, Language Awareness, 21(4), 347-368, doi:10.1080/09658416.2011.616591

Rizvi, F. (2009). 'Towards cosmopolitan learning'. Discourse: studies in the cultural politics of education, 30(3), 253-268. 
Robinson, E., Tian, Z., Martínez, T., \& Qarqeen, A. (2018). Teaching For Justice: Introducing Translanguaging in an Undergraduate TESOL Course. Journal of Language and Education, 4(3), 77-87. doi:10.17323/2411-7390-2018-4-3-7787

Seddon, T., Arnold, B., \& Barbousas, J. (2021). The education minister wants graduating teachers to be 'classroom-ready'. But the classroom is not what it used to be. Retrieved from https:// theconversation.com/the-education-minister-wantsgraduating-teachers-to-be-classroom-ready-but-the-classroomis-not-what-it-used-to-be-159051 (20 April 2021).

Shine, K. (2020). 'Everything is negative': Schoolteachers' perceptions of news coverage of education. Journalism 21(11), 1694-1709.

Stewart, T. (2006). Teacher-Researcher Collaboration or Teachers' Research? TESOL Quarterly, 40(2). 421-430.

Swain M. (2006). Languaging, agency and collaboration in advanced second language proficiency. In H. Byrnes (Ed.), Advanced Language Learning: The Contribution of Halliday and Vygotsky (pp. 95-108). London: Continuum.

Tertiary Education Quality and Standards Agency (TEQSA). (2020). Foundations for good practice: The student experience of online learning in Australian higher education during the COVID19 pandemic. Retrieved from https://www.teqsa.gov.au/ sites/default/files/student-experience-of-online-learning-inaustralian-he-during-covid-19.pdf?v $=1606442611$

Tran, L. (2020). Understanding the full value of international students, https:// www.universityworldnews.com/post. php?story=20200820103708349 (20 August 2020)

UNICEF (Regional Office for Europe and Central Asia). (2020). Building Resilient Education Systems beyond the COVID-19 Pandemic: Considerations for education decision-makers at national, local and school levels. Retrieved from https://www. unicef.org/ukraine/media/8011/file/ECAR\%20 CONSIDERATIONS\%20FOR\%20EDUCATION\%20 PROVISION-\%20v2.5\%20ENG.pdf

Weinmann, M., Arber, R., \& Neilsen, R. (2021). Interrogating the 'normal': (Noticing) the hidden discourses in language teachers' everyday conversations. In R. Arber, M. Weinmann \& J. Blackmore (Eds.) Rethinking Languages Education: 
Directions, Challenges and Innovations (pp. 84-98). Abingdon: Routledge.

Weinmann, M., Slavich, S., \& Neilsen R. (2021). Multiculturalism and the "broken" discourses of Chinese language education. In: C. Halse \& K. Kennedy (Eds.). The future of multiculturalism in turbulent times. Asia-Europe Education Dialogue series. Abingdon: Routledge, Taylor \& Francis.

Weinmann, M., \& Welsh, A. (2021). Looking to Languages: New opportunities right on our doorstep. Retrieved from https:// asialink.unimelb.edu.au/stories/looking-to-languages-newopportunities-right-on-our-doorstep (26 Feb 2021)

Zembylas, M., \& Papamichael, E. (2017). Pedagogies of discomfort and empathy in multicultural teacher education. Intercultural Education, 28(1), 1-19. doi:10.1080/14675986.2017.1288448

Zentrum für Lehrerinnen- und Lehrerbildung Bamberg (ZLB). (2020). Teaching worldwide during the Covid-19 pandemic. Retrieved from https://www.uni-bamberg.de/en/zlb/k-r/ internationalisation-bateg/teaching-worldwide-during-thecovid-19-pandemic/ 